\title{
Circulating Pituitary and Gonadal Hormones in Spring-born Thoroughbred Fillies and Colts from Birth to Puberty
}

\author{
Pramod DHAKAL ${ }^{1,2)}$, Akiko HIRAMA ${ }^{3)}$, Yasuo NAMBO ${ }^{4,5)}$, Takehiro HARADA ${ }^{1,2)}$, \\ Fumio SATO ${ }^{4,5)}$, Kentaro NAGAOKA ${ }^{1,2)}$, Gen WATANABE ${ }^{1,2)}$, and Kazuyoshi TAYA ${ }^{1,2)}$ \\ 1) Department of Basic Veterinary Science, United Graduate School of Veterinary Sciences, Gifu University, \\ Gifu 501-1193, Japan \\ 2) Laboratory of Veterinary Physiology, Cooperative Department of Veterinary Medicine, Faculty of Agriculture, \\ Tokyo University of Agriculture and Technology, Tokyo 183-8509, Japan \\ 3) Miho Training Center, Japan Racing Association, Ibaraki 300-0415, Japan \\ ${ }^{4)}$ Department of Clinical Veterinary Science, United Graduate School of Veterinary Sciences, Gifu University, \\ Gifu 501-1193, Japan \\ 5) Hidaka Training and Research Center, Japan Racing Association, Hokkaido 057-0171, Japan
}

\begin{abstract}
The present study was conducted to elucidate the profile of circulating gonadotropins and gonadal hormones from birth to puberty and relationship between gonadal seasonality and hormonal secretion in both sexes of Thoroughbred horses. Spring-born colts $(n=6)$ and fillies $(n=9)$ were blood sampled weekly from jugular vein from birth to 60 weeks of age. Circulating FSH, LH, prolactin, testosterone, progesterone, estradiol-17 $\beta$, and immunoreactive (ir)-inhibin were measured by radioimmunoassay. In both sexes, the steroid hormones levels were remarkably high at birth, rapidly dropped within a week and remained at the lower levels until the start of second spring after birth. Ir-inhibin was also high during the birth, remaining lowest during winter and again increasing towards the second summer. There was an increase in FSH concentration in foals during the first summer months after birth and in the next summer, the FSH concentration along with that of LH increased significantly. The seasonal increase in circulating prolactin was remarkable even in the first year, and no differences were noted between the two summers. These results clearly demonstrated that the hypothalamo-pituitary axis is already responsive to changes in photoperiod and secrete prolactin similar to adult horses, but pituitary gonadotrophs for FSH and LH secretion is less sensitive. When the values of these hormones in the second breeding season after birth were compared with adult values of the respective sex in the breeding season, no significant differences were observed, indicating that spring-born fillies and colts have already attained the stage of puberty at the second breeding season after birth.
\end{abstract}

Key words: Prolactin, Puberty, Seasonality, Thoroughbred

(J. Reprod. Dev. 58: 522-530, 2012)

$\mathbf{E}_{\mathrm{s}}$ quines are seasonal breeders with activity being highest as days grow longer [1]. There is no univocal reporting of the age of puberty in horses, which has been reported to vary in the range of 7.8-37 months [2]. This variation can be attributed to differences in breeds [3-5], locales, management and puberty definition [6, 7]. Furthermore, there have been few studies on Thoroughbreds [7-9], and most of them were conducted in southern hemisphere. Geographical location influences the season, and there have been fewer reports regarding puberty in horses from the northern hemisphere.

There is a dearth of information on the characteristics of circulating gonadotropins and gonadal hormones in Thoroughbred foals immediately after birth through pre-pubertal age until puberty. Previous studies provided information on relatively shorter periods $[10,11]$ of developmental periods after birth, and those studies focused on certain hormones $[3,4,6]$ only. In seasonal breeders, there is

Received: November 9, 2011

Accepted: April 19, 2012

Published online in J-STAGE: May 19, 2012

(C)2012 by the Society for Reproduction and Development

Correspondence: K Taya (e-mail: taya@cc.tuat.ac.jp) evidence for the involvement of both photoperiodic cues and degree of maturity in the onset of puberty [8]. The photoperiodic information is thought to be conveyed to the reproductive and prolactin axis via changes in circulating concentrations of melatonin [12]. To date, sequential profiling of prolactin has not been done in horses for a long term after birth.

Puberty is a process that results from a complex series of coordinated neuroendocrine changes leading to internal and external physical changes in primary and secondary sexual characteristics and eventual reproductive competence. Although spermatogenesis [13] continues throughout the year in stallions, the reproductive ability is optimal in the breeding seasons. Similarly, mares are seasonal in reproduction [14], the reproductive activity being highest in spring and summer months. A review on puberty of horse [2] indicates that the focus has been on a single sex with reference to specific hormones. The aim of the present study was to perform an integrated study involving both sexes (colts and fillies) with thorough consideration of major hormonal regulators of the hypothalamo-pituitary-gonadal (HPG) axis.

Despite many criteria for distinguishing puberty in animals, the criteria followed by Brown-Douglas et al. [8] with supporting data from comparison with adult Thoroughbred values has been adopted 
in this study. The objectives of this study were to 1) develop a profile of pituitary and gonadal hormones from birth until 60 weeks of age in spring-born Thoroughbred male and female foals, 2) determine approximate age at puberty of spring-born colts and fillies with reference to adult values in the breeding season, and 3) find out the association between seasonality and prolactin hormone in spring-born Thoroughbred colts and fillies.

\section{Materials and Methods}

\section{Animals}

Six colts and nine fillies born during spring from Thoroughbred broodmares kept at the Equine Research Institute of the Japan Racing Association (JRA), located in Utsunomiya ( $36^{\circ} 33^{\prime} 36^{\prime}$ "N), Tochigi, Japan were used in this experiment. Secondary data on daylength was procured from the website of the Japan Meteorological Agency. The subjects were born in spring, from mid April to the end of May. The newborns were allowed outdoors in a pasture with their dams from the second day after birth for a few hours a day. After 2 weeks, they were kept indoors at night and outdoors during the day for $7 \mathrm{~h}$. Foals were fed with a fistful of pellet diet twice daily after they were 2 months old. They were weaned at 6 months and switched to a balanced diet (JRA standards, Hidaka, Japan). On reaching one year of age, the colts and fillies were separated and kept in a pasture. Seven fertile mares (5-9 years old) and 10 stallions (6-8 years old) were employed for the comparative study with fillies and colts respectively.

\section{Body weight and blood sampling}

Weekly blood samples were taken from colts and fillies at 1300 $1400 \mathrm{~h}$ from birth until 60 weeks of age for the analysis of changes in circulating follicle-stimulating hormone (FSH), luteinizing hormone $(\mathrm{LH})$, prolactin, immunoreactive inhibin (ir-inhibin), testosterone, progesterone, and estradiol-17 3 . Weekly body weights were measured using a standard weighing machine for large animals. Blood samples were taken twice a week in mares during the the estrous cycle (follicular and luteal phase) during March and April and once a month in stallions during the breeding (March-September) and non-breeding (October-February) seasons for a period of two years. Blood samples were collected from Jugular vein into heparinized vacutainers. Plasma was harvested and stored at $-20 \mathrm{C}$ until assayed.

\section{Radioimmunoassay of FSH, LH, ir-inhibin, testosterone, progesterone, and prolactin}

The plasma concentration of FSH and LH were determined by homologous double-antibody equine RIA methods as described previously [15]. The intra- and inter-assay coefficients of variance were $4.9 \%$ and $12.2 \%$ for FSH and $12.6 \%$ and $15.1 \%$ for $\mathrm{LH}$, respectively. The concentrations progesterone, testosterone and estradiol-17 $\beta$ were determined by double-antibody RIA systems using ${ }^{125}$ I-labeled radioligands as previously described [16]. Antisera against progesterone (GDN 337), testosterone (GDN 250) and estradiol-17 $\beta$ (GDN 244) were used in each RIA. The intra- and interassay coefficients of variance were $7.3 \%$ and $14.3 \%$ for progesterone, $6.3 \%$ and $7.2 \%$ for testosterone and $6.7 \%$ and $17.8 \%$ for estradiol-17 $\beta$, respectively. Plasma ir-inhibin concentrations were measured using a rabbit antiserum against purified bovine inhibin (TNDH 1, Laboratory of Veterinary Physiology, Tokyo University of Agriculture and Technology ) and ${ }^{125}$ I-labeled $32-\mathrm{kDa}$ bovine inhibin, as previously described [17]. The results were expressed in terms of 32-kDa bovine inhibin. The intra- and interassay coefficients of variance were $8.0 \%$ and $16.2 \%$, respectively. The plasma concentration of prolactin was measured by RIA using rat anti-sera against equine prolactin (AFP-261987) and a reference standard (AFP-8794B) as previously described [1]. The intra- and interassay coefficients of variance were $7.1 \%$ and $9.8 \%$ respectively.

\section{Statistical analysis}

The birth date ranges for the fillies and colts were 54 and 43 days respectively, and the mean birth date (May 7 for fillies and May 1 for colts) was calculated; the data were mounted over ages of 1-60 weeks. All the values were expressed as means \pm SEM. Data for breeding season were calculated by taking the averages of values falling in between March 21 and September 23, and rest of the values in a year were regarded as belonging to the non-breeding season. One-way ANOVA with Tukey's multiple comparison tests was performed to detect the significant changes in the concentration of hormones from the birth until 60 weeks of age. Pearson's $r$ was calculated to find correlation between variables. Values were considered significant at $\mathrm{P}<0.05$. All calculations were performed using GraphPad Prism version 5.00 for Windows (GraphPad Software, San Diego, California USA; www.graphpad.com).

\section{Results}

\section{Body weight}

The mean weight (Fig. 1a) of the colts $(55.8 \pm 5.1 \mathrm{~kg})$ at birth was greater than that of the fillies $(54.2 \pm 5.7 \mathrm{~kg})$. Fillies had an accelerated growth, surpassed the weight of the colts within a week $(67 \pm 4.4 \mathrm{~kg}$ vs. $64 \pm 10.4 \mathrm{~kg}$ ) and maintained the superiority throughout the rest of the age. Both sexes weighed double their birth weight at the age of 11 weeks. At the end of the study period, colts and fillies were $373.7 \pm 19.2 \mathrm{~kg}$ and $387.8 \pm 18.2 \mathrm{~kg}$, respectively. The weekly gain of body weight (Fig. 1b) showed a decreasing tendency with the increase in age in both sexes. Colts and fillies showed a significant negative nonlinear trend (slope $=-0.042$ and -0.041 respectively, $\mathrm{P}<0.0001$ ) in the body weight gain per week with advancing age. There was no statistical significance for the difference in weights between colts and fillies at any point of age. Fillies attained puberty by 52 weeks of age, at which time they weighed $352.5 \pm 4.9 \mathrm{~kg}$, and colts attained puberty at 54 weeks, at which time they weighed $348.7 \pm 5.5 \mathrm{~kg}$.

\section{LH, FSH and ir-inhibin}

Filly: LH (Fig. 2a) remained at its basal level after the birth and started rising after 45 weeks of age. By 53 weeks of age, the value $(2.39 \pm 1.27 \mathrm{ng} / \mathrm{ml})$ was significantly higher than at the birth $(0.27 \pm 0.12 \mathrm{ng} / \mathrm{ml})$. LH was at its maximum $(4.32 \pm 0.97 \mathrm{ng} / \mathrm{ml})$ when fillies reached the age of 58 weeks. There was no significant difference in the mean $\mathrm{LH}$ value in the second breeding season when compared with the luteal phase LH of mares (Fig. 3a). The FSH (Fig. 2b) value of the fillies was at the basal level $(1.21 \pm 0.15$ 


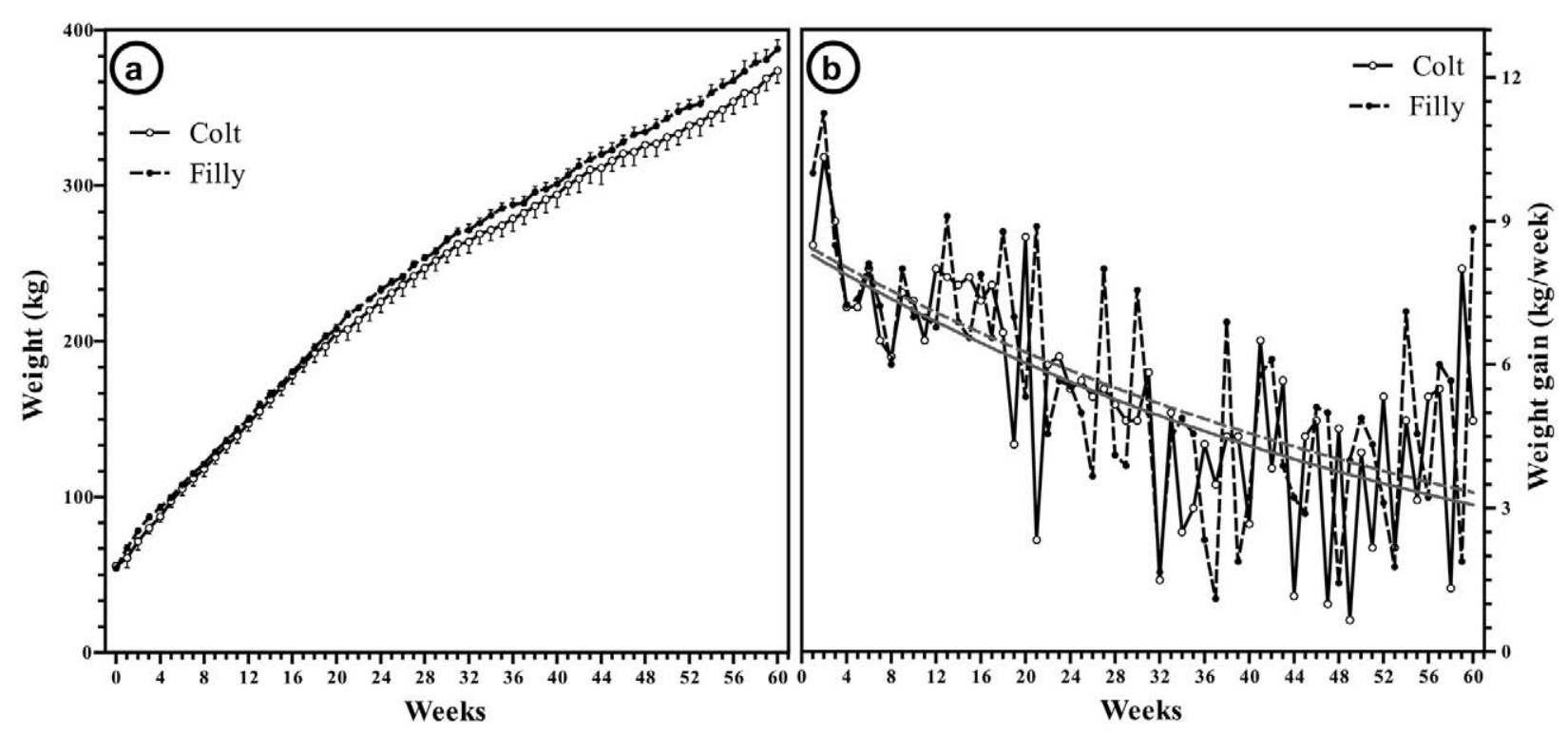

Fig. 1. Weekly means \pm SEM a) body weights and b) body weight gain and their nonlinear regression (light color) in colts and fillies.

$\mathrm{ng} / \mathrm{ml}$ ) at birth, which increased but nonsignificantly after 6 weeks, and reached $3.28 \pm 1.70 \mathrm{ng} / \mathrm{ml}$ at 13 weeks of age and then slowly decreased towards the non-breeding season. In the next breeding season at 48 weeks of age, the value $(5.10 \pm 1.16 \mathrm{ng} / \mathrm{ml})$ increased significantly, continued to increase and reached the maximum value $(7.53 \pm 1.29 \mathrm{ng} / \mathrm{ml})$ at 58 weeks; there was no significant difference in the mean FSH value in the second breeding season when compared with FSH in mare in the breeding season (Fig. 3b). The fillies were born with a high amount $(2.69 \pm 0.37 \mathrm{ng} / \mathrm{ml})$ of ir-inhibin (Fig. 2f), which dropped significantly to $1.82 \pm 0.31 \mathrm{ng} / \mathrm{ml}$ in the following week and continued to decrease towards winter, reaching the lowest value $(0.49 \pm 0.04 \mathrm{ng} / \mathrm{ml})$ at 30 weeks of age. Increasing values were observed towards the summer months, and maximum value, $1.10 \pm 0.16$ was reached at 54 weeks of age in the second breeding season, the average for which was eqal to that of mare's ir-inhibin value (Fig. 3f) .

Colt: There was a nonsignificant increase in LH (Fig. 4a) at 7 weeks $(0.31 \pm 0.12 \mathrm{ng} / \mathrm{ml})$ after birth $(0.15 \pm 0.04 \mathrm{ng} / \mathrm{ml})$, which declined towards the non-breeding season and reached its nadir $(0.07$ $\pm 0.01 \mathrm{ng} / \mathrm{ml})$ in February at 34 weeks of age. The value started to increase in spring and reached the significantly highest point $(0.57$ $\pm 0.21 \mathrm{ng} / \mathrm{ml}$ ) at 50 weeks of age. During birth, the FSH level (Fig. 4b) was $1.18 \pm 0.32 \mathrm{ng} / \mathrm{ml}$, and it increased nonsignificantly, reached the maximum value $(1.87 \pm 0.19 \mathrm{ng} / \mathrm{ml})$ at 11 weeks of age and then dropped towards the fall months. Beginning at 35 weeks of age in winter, FSH started to increase and reached a significantly high concentration $(3.99 \pm 1.00 \mathrm{ng} / \mathrm{ml})$ at 46 weeks of age in spring. It was at its maximum $(4.40 \pm 1.82 \mathrm{ng} / \mathrm{ml})$ at 52 weeks and started to drop towards the end of breeding season. Colts were also born with a high concentration $(1.49 \pm 0.29 \mathrm{ng} / \mathrm{ml})$ of ir-inhibin (Fig. $4 \mathrm{f})$ that slowly decreased towards the significantly lowest value $(0.54 \pm$ $0.07 \mathrm{ng} / \mathrm{ml})$ in fall at 21 weeks of age. Its nadir, $0.52 \pm 0.04 \mathrm{ng} / \mathrm{ml}$, was observed at 32 weeks in winter, and the value rose gradually towards the point of significance $(1.34 \pm 0.32 \mathrm{ng} / \mathrm{ml})$ at 56 weeks of age in the next summer and then reached the maximum value, $1.52 \pm$ $0.38 \mathrm{ng} / \mathrm{ml}$, by the end of study period. The average concentrations of LH, FSH and ir-inhibin were not significantly different between colts in the second breeding season and stallions in breeding season (Fig. 5a, 5b, and 5f).

\section{Progesterone, estradiol-17 $\beta$ and testosterone}

Filly: Fillies were born with a high plasma concentration (5.52 $\pm 1.77 \mathrm{ng} / \mathrm{ml}$ ) of progesterone (Fig. 2d) that dropped significantly $(1.20 \pm 0.79 \mathrm{ng} / \mathrm{ml})$ in the following week and remained at the basal level (below $0.3 \mathrm{ng} / \mathrm{ml}$ ) from 3 to 47 weeks of age. The value started to increase at 48 weeks $(0.97 \pm 0.76 \mathrm{ng} / \mathrm{ml})$ of age in the next spring, and significantly exceeded the non-breeding season values at the age of 52 weeks $(4.10 \pm 1.07 \mathrm{ng} / \mathrm{ml})$ and maintained dominance thenafter. Their average value in the second breeding season approached the progesterone levels of mares in the luteal phase (Fig. 3d). The plasma concentration of estradiol-17 $\beta$ (Fig. 2e) was also significantly high $(153.99 \pm 20.12 \mathrm{pg} / \mathrm{ml})$ at birth then dropped significantly in the second week $(58.87 \pm 15.10 \mathrm{pg} / \mathrm{ml})$. The value slowly dropped towards the mid winter and reached its nadir, $9.62 \pm 1.47 \mathrm{pg} / \mathrm{ml}$, at 33 weeks. Beginning at 47 weeks of age in spring, it started to increase $(45.74 \pm 11.22 \mathrm{pg} / \mathrm{ml})$ and reached a peak of $76.29 \pm 33.10 \mathrm{pg} / \mathrm{ml}$ at 50 weeks. The plasma concentration of estradiol-17 $\beta$ in fillies in the second breeding season was similar to the mare's level in the follicular phase (Fig. 3e).

Colt: Colts were born with a high plasma concentration (619.10 $\pm 152.48 \mathrm{pg} / \mathrm{ml}$ ) of testosterone (Fig. $4 \mathrm{~d}$ ) that significantly fell to $90.23 \pm 13.28 \mathrm{pg} / \mathrm{ml}$ in the second week and then remained at the baseline prior to 47 weeks $(305.31 \pm 38.12 \mathrm{pg} / \mathrm{ml})$ of age in spring, at which point the value was significantly higher than the baseline values. The maximum concentration, $578.91 \pm 150.55 \mathrm{pg} / \mathrm{ml}$, was observed at 54 weeks of age. The plasma concentration of estradiol-17 $\beta$ 

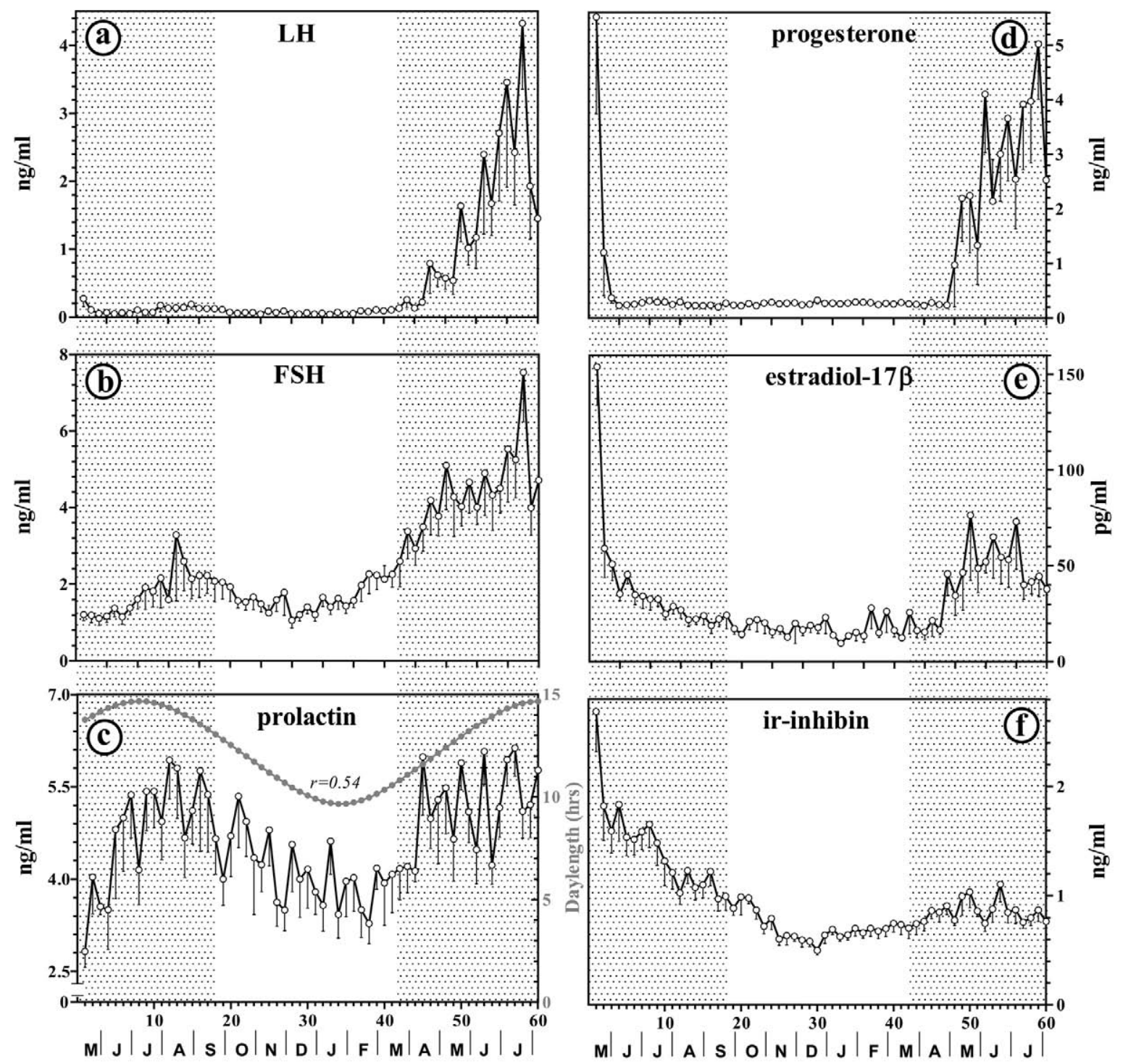

\section{Age of fillies in weeks and respective months}

Fig. 2. Weekly hormonal profile of a) $\mathrm{LH}$, b) FSH, c) prolactin, d) progesterone, e) estradiol-17 $\beta$ and f) ir-inhibin from birth to 60 weeks of age in fillies. Note the correlation between day length (light color) and prolactin in Fig. c. The shaded portions represent the natural breeding seasons. Results are expressed as means \pm SEM of 9 animals.

(Fig. 4e) varied greatly among the colts. It was high at birth, with a range of 48.19-291.03 pg/ml, and then decreased in all individuals towards the winter months. In one colt in particularly, the first burst in estradiol-17 $(595.95 \mathrm{pg} / \mathrm{ml})$ was noticed at 43 weeks, and the value increased further and peaked $(776.13 \mathrm{pg} / \mathrm{ml})$ at 52 weeks of age. There were no significant differences in the plasma concentrations of testosterone (Fig. 5d) and estradiol-17 (Fig. 5e) between colts in the second breeding season and stallions in the breeding season.

\section{Prolactin}

Fillies and colts had a low prolactin concentration in circulation at birth, the value being $2.82 \pm 0.26$ (Fig. 2c) and $3.68 \pm 0.27$ (Fig. 4c) $\mathrm{ng} / \mathrm{ml}$ respectively. It started to increase towards the summer months after birth and reached a significantly high value of $5.93 \pm$ $0.63 \mathrm{ng} / \mathrm{ml}$ for fillies at 12 weeks and $8.44 \pm 1.87 \mathrm{ng} / \mathrm{ml}$ for colts at 11 weeks. These values started to decrease towards a minimum of $3.28 \pm 0.33 \mathrm{ng} / \mathrm{ml}$ at 38 weeks for fillies and $3.95 \pm 0.34 \mathrm{ng} / \mathrm{ml}$ at 39 weeks for colts. With the advance of spring, the concentration rose again and significantly differed at 57 and 58 weeks for fillies $(6.13 \pm 0.45 \mathrm{ng} / \mathrm{ml})$ and colts $(9.85 \pm 2.20 \mathrm{ng} / \mathrm{ml})$ respectively, when compared with the winter minimal values. The average concentrations of prolactin in both breeding seasons for fillies (Fig. 3c) and colts (Fig. 5c) were the same as the levels of mare and stallion (Figs. 3c and $5 \mathrm{c}$ ) respectively in the breeding season. The plasma concentration 

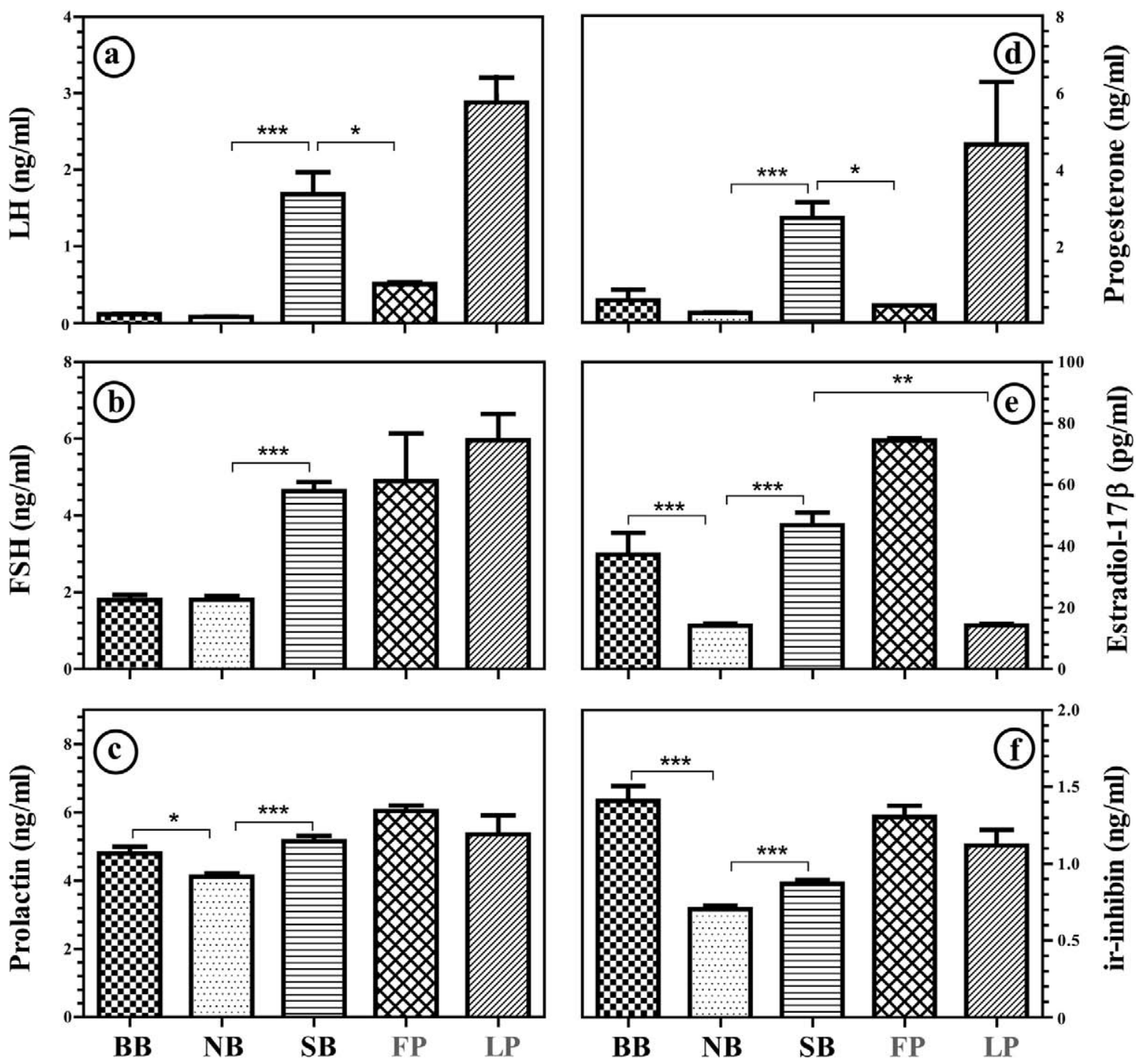

Fig. 3. Average ( \pm SEM) concentrations of a) LH, b) FSH, c) prolactin, d) progesterone, e) estradiol-17 $\beta$ and f) ir-inhibin during the breeding season at birth (BB), non-breeding season (NB) and second breeding season after birth (SB) of fillies $(n=9)$ and comparison of those values with the respective hormone levels in mares $(n=7)$ at the follicular phase (FP) and luteal phase (LP) during breeding season. Significant differences in one-way ANOVA are denoted by ${ }^{*}(\mathrm{P}<0.05),{ }^{* *}(\mathrm{P}<0.001)$ and ${ }^{* * *}(\mathrm{P}<0.0001)$.

of prolactin over the weeks was positively correlated with the day length (Figs. 2c and 4c) of those weeks, with the Pearson correlation coefficient (r) being 0.54 and 0.64 for fillies and colts respectively.

\section{Discussion}

Puberty is associated with increased secretion of gonadotropins, secretion of testosterone, estradiol-17 $\beta$, and progesterone in response to discharge of LH and the start of spermatogenesis [18] and ovulation. It is a precisely coordinated phenomenon of the hypothalamopituitary-gonadal (HPG) axis. Thus, this study takes into account of all the major hormones involved in HPG axis function of both the colts and fillies. Hereafter unless otherwise specified, hormonal descriptions apply to both sexes. There was a small increase in FSH
(Figs. 2b and 4b) in the breeding season of birth, with peaks during third month of life. A post-natal increment in gonadotropins is evident in other species $[19,20]$ and reflects the early follicular increment and progression of testicular maturation respectively, which perhaps is responsible for sexual maturity after puberty. Although there was individual variation, the plasma LH concentration increased slightly after 2 weeks of birth in colts. The plasma concentration of FSH reached significantly higher levels earlier than LH in both sexes in the next breeding season, at which time the animals exceeded 46 weeks of age. Circulating ir-inhibin, the concentration of which was high at birth, slowly decreased with the advance of age of the foals. Equine fetal gonads undergo remarkable enlargement and regression during pregnancy and secrete high amounts of inhibin [21, 22]. This decline in circulating ir-inhibin can be explained by the decreasing 

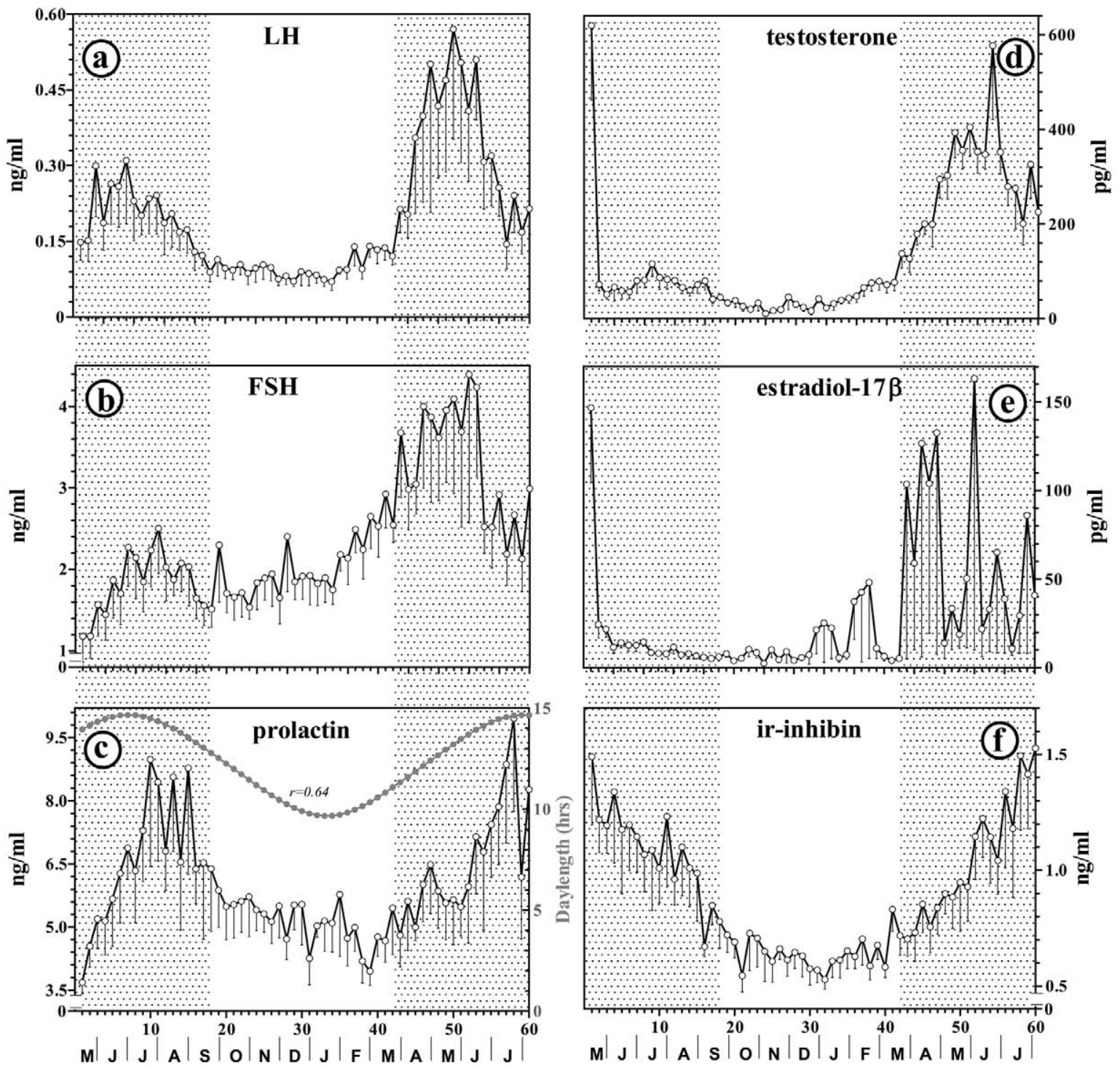

Age of colts in weeks and respective months

Fig. 4. Weekly hormonal profile of a) LH, b) FSH, c) prolactin, d) testosterone, e) estradiol-17ß, and f) ir-inhibin from birth to 60 weeks of age in colts. Note the correlation between day length (light color) and prolactin in Fig. c. The shaded portions represent the natural breeding seasons. Results are expressed as means \pm SEM of 6 animals.

secretion by the regressing gonads after birth with further suppression by the early FSH increase in foals. In the next breeding season, after they reached the age of 56 weeks, the plasma levels of ir-inhibin increased significantly in the colts. Inhibin has been implicated as a marker of testicular function of stallions [23-25], and a gradual increase in circulating inhibin is shown during the follicular phase in mares [26-28].

Both colts and fillies were born with a high amount of steroid hormones that dropped abruptly within 24 hours [10,11]. The fetal gonads of horse provide precursors for maternal estrogens [21,22], and the high concentration at birth is the carryover from the intrauterine maternal environment and subsequent metabolism after birth. During the non-breeding season, all steroids were at the basal level, and in next breeding season after 47 weeks of age, remarkable increments were observed. The reduction in gonadotropins and in turn steroids in the non-breeding winter months could be due to the modulatory role of decreased photoperiod and low hypothalamic GnRH output [29]. The HPG axis is regulated by the negative feedback of steroids on gonadotropins [7], which is difficult to appreciate in this study due to the long interval sampling procedure. However, colts and fillies in this study exhibited a clear increase in gonadotropins and concomitant gonadal steroid hormones during the second breeding season, which indicates that the animals reached puberty.

Considering puberty as a point when progesterone levels exceed 

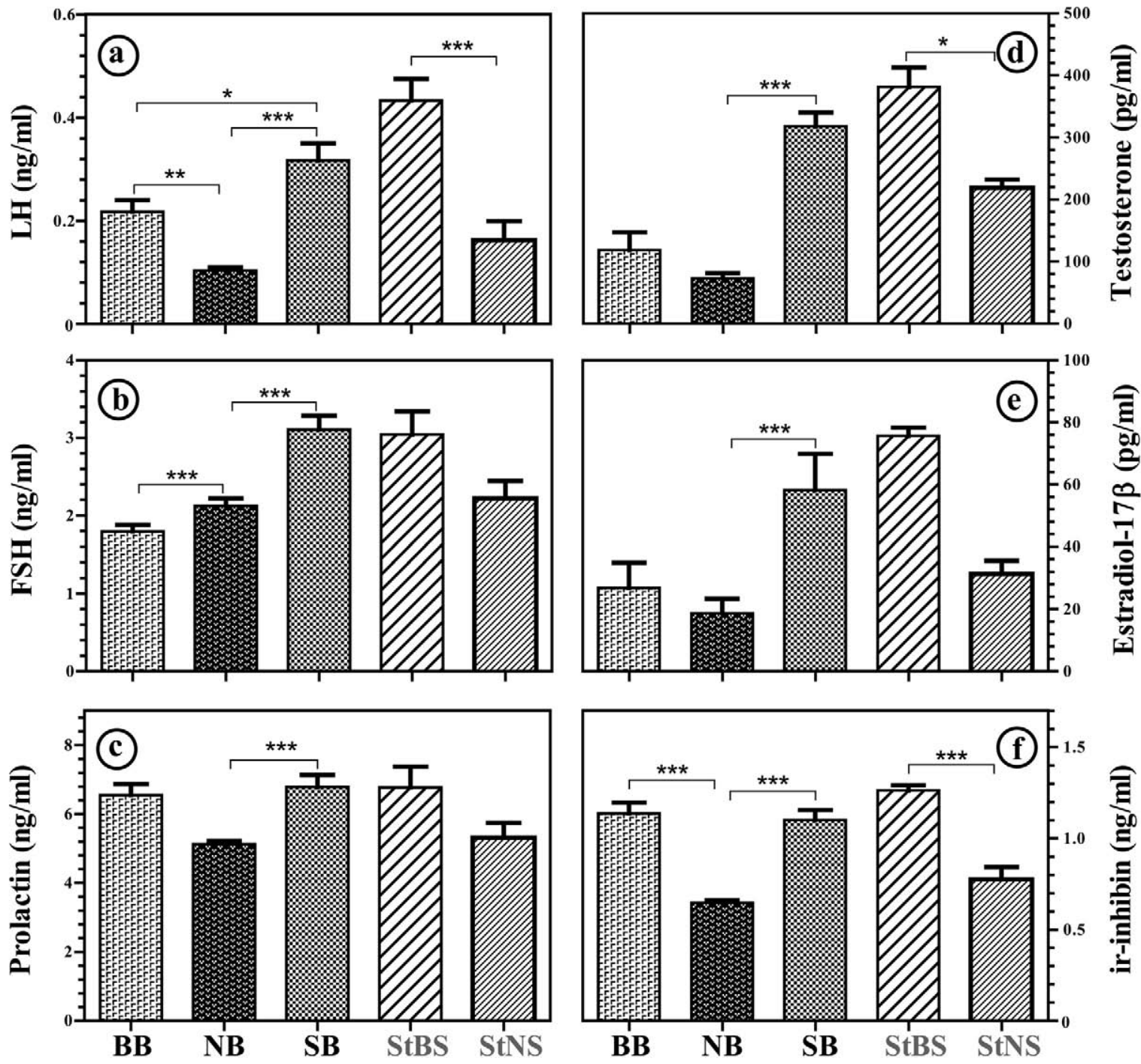

Fig. 5. Average ( \pm SEM) concentrations of a) LH, b) FSH, c) prolactin, d) testosterone, e) estradiol-17 $\beta$ and f) ir-inhibin in the breeding season at birth (BB), non-breeding season (NB) and second breeding season after birth $(\mathrm{SB})$ of colts $(\mathrm{n}=6)$ and comparison of those values with the respective hormone levels in stallions $(n=10)$ during the breeding season (StBS) and non-breeding season (StNB). Significant differences in one-way ANOVA are denoted by ** $(\mathrm{P}<0.001)$ and ${ }^{* *}(\mathrm{P}<0.0001)$.

$2 \mathrm{ng} / \mathrm{ml}[8]$ and rise by 2 standard deviation (SD) above the average value, the fillies reached puberty by 52 weeks of age, at which point they weighed $352.4 \pm 4.9 \mathrm{~kg}$. Similarly, when an excess of $500 \mathrm{pg} /$ $\mathrm{ml}[6]$ and a $2 \mathrm{SD}$ increment aver the average value of testosterone is taken as an indication of pubertal age, colts attained puberty at the age of 54 weeks, at which point they weighed $348.7 \pm 5.5 \mathrm{~kg}$. Colts and fillies had a prepubertal rise in gonadotropins, which is much earlier than the steroid peaks, and such gonadotropin rise has been shown to be a result of increase in pulse frequency in other domestic animals $[18,30]$. Similar phenomenon can be assumed in the case of colts and fillies during the prepubertal period. An earlier study in the southern hemisphere [8] revealed that autumn-born foals reach puberty earlier than spring-born ones but body weight was higher in spring-born foals at puberty. The spring-born foals in that study reached puberty at an age and weight similar to those of the spring-born foals in the present study. When all the hormones concentrations of the colts and fillies in the second breeding season after birth were compared with the respective hormone levels in the stallions and mares in the breeding season, there were no significant differences. This provides additional support to our conclusion that the colts and fillies reached puberty by 60 weeks of age.

The circulating prolactin concentration was episodic in both colts and fillies, the crests being during June-August which is the transition of spring to summer in the northern hemisphere. The trough of the prolactin episode was observed during the months of December-February, which is the nadir of the winter season. In our experiments, prolactin in both sexes correlated positively with the day length. In fact, an earlier study [1] in stallions and 
geldings showed that the correlation is stronger with the daylength than with temperature. It is a known fact that melatonin secretion is lower during increasing photo periods. The prolactin axis of the mare is negatively regulated by melatonin during the spring and early summer months [12]. Notably, the prolactin concentrations were similar between the immediate breeding season at birth and the second breeding season after the birth. This phenomenon was identical in both the colts and fillies. The maturity of animals did not appear to influence the prolactin concentration. Prolactin has been demonstrated to be involved in steroidogenesis [31] in humans and immunization against estrogens did not affect prolactin levels in stallions [32]. Steroid hormones in colts and fillies did not correlate with prolactin in this study also. This is further supported by the result that there is a gonadal-independent effect of season on lactotroph population [33] and an absence of prolactin receptors on gonadotrophs cells [34]. The prolactin hormone profiles of the colts and fillies in this study reflected seasonality without any direct possibility of modulation of other hormones, at least in the breeding season of birth as there was no overall significant correlation of prolactin with gonadal hormones and gonadotropins. The prolactin action on gonadotrophs during the breeding season has recently been shown to be tightly regulated by dopamine [29]. Profiling of dopamine can thus give better understanding of the relationship between prolactin and other hormones. Mares discharge prolactin from follicular fluid into the peritoneal cavity during ovulation, although it may not contribute much to the plasma levels [35]. In general, the increase in prolactin in the breeding season of birth in this study can be taken as an indication of pituitary maturity, especially of the lactotroph in these animals, as the levels are similar to those in the second breeding season which in turn equaled the adult values in the breeding season (Figs. 3 and 5).

In summary this study clarifies the profiles of reproductive hormones secreted from pituitary and gonads of spring-born Thoroughbred colts and fillies from birth until puberty. These spring-born (breeding season) animals had a high amount of steroid hormones that dropped within a week to the nadir, and all hormones measured in this study reached the maximum levels in the next breeding season after birth. Spring-born fillies and colts reached puberty in the next breeding season after birth, and before the age of 60 weeks, when all hormones concentrations and body weight approached the respective adult Thoroughbreds' values. Seasonal high prolactin in young and pubertal horses during the breeding months of the year is independent of the maturity of the animals and is positively correlated with the day length.

\section{Acknowledgments}

We are grateful to the National Hormone and Pituitary Program, NIDDK, NIH (Torrance, CA, USA), and Dr AF Parlow for the equine LH, FSH and prolactin kits and to Dr GD Niswender, Animal Reproduction and Biotechnology Laboratory, Colorado State University (Fort Collins, CO, USA), for providing antisera to progesterone (GDN 337), testosterone (GDN 250) and estradiol$17 \beta$ (GDN 244). We thank Dr Y Suda, Miyagi University, for his advice on statistical analysis. This work was supported by a grantin-aid from the Equine Research Institute of the Japan Racing Association.

\section{References}

1. Dhakal P, Tsunoda N, Nakai R, Ito M, Nagaoka K, Toishi Y, Taniyama H, Watanabe G, Taya K. Annual changes in day-length, temperature, and circulating reproductive hormones in Thoroughbred stallions. J Equine Sci 2011; 22: 29-36. [CrossRef]

2. Elits B. Puberty. In: McKinnon AO, Squires EL, Vaala WE, Varner DD (eds.), Equine Reproduction. West Sussex: Wiley-Blackwell; 2011: 1689-1695.

3. Wesson JA, Ginther OJ. Puberty in the male pony -plasma gonadotropin concentrations and the effects of castration. Anim Reprod Sci 1981; 4: 165-175. [CrossRef]

4. Wesson JA, Ginther OJ. Puberty in the female pony - reproductive-behavior, ovulation, and plasma gonadotropin concentrations. Biol Reprod 1981; 24: 977-986. [Medline] [CrossRef]

5. Brown-Douglas CG, Parkinson TJ, Firth EC, Fennessy PF. Bodyweights and growth rates of spring- and autumn-born thoroughbred horses raised on pasture. NZ Vet J 2005; 53: 326-331. [Medline] [CrossRef]

6. Naden J, Amann RP, Squires EL. Testicular growth, hormone concentrations, seminal characteristics and sexual behaviour in stallions. J Reprod Fertil 1990; 88: 167-176. [Medline] [CrossRef]

7. Nogueira GP. Follicle profile and plasma gonadotropin concentration in pubertal female ponies. Braz J Med Biol Res 2004; 37: 913-922. [Medline] [CrossRef]

8. Brown-Douglas CG, Firth EC, Parkinson TJ, Fennessy PF. Onset of puberty in pasture-raised Thoroughbreds born in southern hemisphere spring and autumn. Equine Vet $J$ 2004; 36: 499-504. [Medline] [CrossRef]

9. Brown-Douglas CG, Firth EC, Parkinson TJ, Fennessy PF. The pituitary and testicular responses to $\mathrm{GnRH}$ challenge between 4 and 14 months of age in thoroughbred colts born in spring and autumn. Anim Reprod Sci 2005; 88: 287-298. [Medline] [CrossRef]

10. Dhakal P, Tsunoda N, Nakai R, Nagaoka K, Nambo Y, Sato F, Taniyama H, Watanabe G, Taya K. Post-natal dynamic changes in circulating follicle-stimulating hormone, luteinizing hormone, immunoreactive inhibin, progesterone, testosterone and estradiol$17 \beta$ in Thoroughbred colts until 6 months of age. J Equine Sci 2011; 22: 9-15. [CrossRef]

11. Nakai R, Weng Q, Tanaka Y, Tsunoda N, Taniyama H, Haramaki S, Nambo Y, Watanabe G, Taya K. Change in circulating follicle-stimulating hormone, luteinizing hormone, immunoreactive inhibin, progesterone, testosterone and estradiol-17 $\beta$ in fillies from birth to 6 months of age. J Equine Sci 2007; 18: 85-91. [CrossRef]

12. Fitzgerald BP, Davison LA, McManus CJ. Evidence for a seasonal variation in the ability of exogenous melatonin to suppress prolactin secretion in the mare. Domest Anim Endocrinol 2000; 18: 395-408. [Medline] [CrossRef]

13. Johnson L. Increased daily sperm production in the breeding season of stallions is explained by an elevated population of spermatogonia. Biol Reprod 1985; 32: 1181-1190. [Medline] [CrossRef]

14. Ginther OJ. Reproductive seasonality. In: Reproductive Biology of the Mare -Basic and Applied Aspects. Cross Plains, Winsconsin: Equiservices; 1992: 105-135.

15. Medan MS, Nambo Y, Nagamine N, Shinbo H, Watanabe G, Groome N, Taya K. Plasma concentrations of ir-inhibin, inhibin A, inhibin pro- $\alpha \mathrm{C}, \mathrm{FSH}$, and estradiol-17 $\beta$ during estrous cycle in mares and their relationship with follicular growth. Endocrine 2004; 25: 7-14. [Medline] [CrossRef]

16. Taya K, Watanabe G, Sasamoto $\mathrm{S}$. Radioimmunoassay for progesterone, testosterone and estradiol-17ß 125I-iodohistamine radioligands. Jpn J Anim Reprod 1985; 31: 186 197. [CrossRef]

17. Hamada T, Watanabe G, Kokuho T, Taya K, Sasamoto S, Hasegawa Y, Miyamoto K, Igarashi M. Radioimmunoassay of inhibin in various mammals. J Endocrinol 1989; 122: 697-704. [Medline] [CrossRef]

18. Amann RP, Walker OA. Changes in the pituitary-gonadal axis associated with puberty in Holstein bulls. J Anim Sci 1983; 57: 433-442. [Medline]

19. Mahdi D, Khallili K. Relationship between follicle growth and circulating gonadotrophin levels during postnatal development of sheep. Anim Reprod Sci 2008; 106: 100-112. [Medline] [CrossRef]

20. Chandolia RK, Honaramooz A, Bartlewski PM, Beard AP, Rawlings NC. Effects of treatment with LH releasing hormone before the early increase in LH secretion on endocrine and reproductive development in bull calves. J Reprod Fertil 1997; 111: 41-50. [Medline] [CrossRef]

21. Tanaka Y, Taniyama H, Tsunoda N, Herath CB, Nakai R, Shinbo H, Nagamine N, Nambo Y, Nagata S, Watanabe G, Groome NP, Taya K. Localization and secretion of inhibins in the equine fetal ovaries. Biol Reprod 2003; 68: 328-335. [Medline] [CrossRef]

22. Tanaka Y, Taniyama H, Tsunoda N, Shinbo H, Nagamine N, Nambo Y, Nagata S, Watanabe G, Herath CB, Groome NP, Taya K. The testis as a major source of circulating inhibins in the male equine fetus during the second half of gestation. $J$ Androl 2002; 23: 229-236. [Medline]

23. Taya K, Nagata S, Tsunoda N, Nagamine N, Tanaka Y, Nagaoka K, Taniyama H, Nambo Y, Watanabe G. Testicular secretion of inhibin in stallions. J Reprod Fertil Suppl 2000; 56: 43-50. [Medline] 
24. Nagata S, Tsunoda N, Nagamine N, Tanaka Y, Taniyama H, Nambo Y, Watanabe G, Taya K. Testicular inhibin in the stallion: cellular source and seasonal changes in its secretion. Biol Reprod 1998; 59: 62-68. [Medline] [CrossRef]

25. Nagata S, Miyake YI, Nambo Y, Nagamine N, Watanabe G, Tsunoda N, Taniyama H, Hondo E, Yamada J, Taya K. Inhibin secretion in the stallion. Equine Vet $J$ 1998; 30: 98-103. [Medline] [CrossRef]

26. Nagaoka K, Nambo Y, Nagamine N, Nagata SI, Tanaka Y, Shinbo H, Tsunoda N, Taniyama H, Watanabe G, Groome NP, Taya K. A selective increase in circulating inhibin and inhibin pro-alphaC at the time of ovulation in the mare. Am J Physiol 1999; 277: E870-E875. [Medline]

27. Nambo Y, Nagaoka K, Tanaka Y, Nagamine N, Shinbo H, Nagata S, Yoshihara T, Watanabe G, Groome NP, Taya K. Mechanisms responsible for increase in circulating inhibin levels at the time of ovulation in mares. Theriogenology 2002; 57: 1707-1717. [Medline] [CrossRef]

28. Nagamine N, Nambo Y, Nagata S, Nagaoka K, Tsunoda N, Taniyama H, Tanaka Y, Tohei A, Watanabe G, Taya K. Inhibin secretion in the mare: localization of inhibin alpha, betaA, and betaB subunits in the ovary. Biol Reprod 1998; 59: 1392-1398. [Medline] [CrossRef]

29. Hodson DJ, Townsend J, Gregory SJ, Walters C, Tortonese DJ. Role of prolactin in the gonadotroph responsiveness to gonadotrophin-releasing hormone during the equine annual reproductive cycle. J Neuroendocrinol 2010; 22: 509-517. [Medline] [CrossRef]

30. Foster DL, Mickelson IH, Ryan KD, Coon GA, Drongowski RA, Holt JA. Ontogeny of pulsatile luteinizing hormone and testosterone secretion in male lambs. Endocrinology 1978; 102: 1137-1146. [Medline] [CrossRef]

31. Glasow A, Breidert M, Haidan A, Anderegg U, Kelly PA, Bornstein SR. Functiona aspects of the effect of prolactin (PRL) on adrenal steroidogenesis and distribution of the PRL receptor in the human adrenal gland. J Clin Endocrinol Metab 1996; 81: 3103-3111. [Medline] [CrossRef]

32. Thompson DL Jr, Johnson L. Effects of age, season and active immunization against estrogen on serum prolactin concentrations in stallions. Domest Anim Endocrinol 1987; 4 17-22. [Medline] [CrossRef]

33. Townsend J, Sneddon CL, Tortonese DJ. Gonadotroph heterogeneity, density and distribution, and gonadotroph-lactotroph associations in the pars distalis of the male equine pituitary gland. J Neuroendocrinol 2004; 16: 432-440. [Medline] [CrossRef]

34. Gregory SJ, Brooks J, McNeilly AS, Ingleton PM, Tortonese DJ. Gonadotrophlactotroph associations and expression of prolactin receptors in the equine pituitary gland throughout the seasonal reproductive cycle. J Reprod Fertil 2000; 119: 223-231. [Medline] [CrossRef]

35. King SS, Roser JF, Jones KL. Follicular fluid prolactin and the periovulatory prolactin surge in the mare. J Equine Vet Sci 2008; 28: 468-472. [CrossRef] 